Article

\title{
State and Current Trends in the Development of the Social Service System in Russia
}

\author{
Maxim A. Shestakov ${ }^{1}$, Vladimir M. Smirnov ${ }^{1}$ and Marina V. Danilina ${ }^{1,2,3, *(\mathbb{D})}$ \\ 1 Department of Economics, FGBU VNII of Labour, Ministry of Labour of the Russian Federation, \\ 4th Parkovaya, 29, 105043 Moscow, Russia; shestakov_ma@mail.ru (M.A.S.); vsmirnov@vcot.info (V.M.S.) \\ 2 Department of Economics, Finance University under the Government of the Russian Federation, \\ Leningradsky Prospect, 49, 125993 Moscow, Russia \\ 3 Department of Economics, Plekhanov Russian University of Economics (PRUE), Stremyanny per., 36, \\ 117997 Moscow, Russia \\ * Correspondence: marinadanilina@yandex.ru; Tel.: +7-910-430-7831
}

check for updates

Citation: Shestakov, Maxim A., Vladimir M. Smirnov, and Marina V. Danilina. 2022. State and Current Trends in the Development of the Social Service System in Russia. Economies 10: 32. https://doi.org/ 10.3390/economies10020032

Academic Editor: Ralf Fendel

Received: 30 November 2021

Accepted: 18 January 2022

Published: 27 January 2022

Publisher's Note: MDPI stays neutral with regard to jurisdictional claims in published maps and institutional affiliations.

Copyright: (c) 2022 by the authors. Licensee MDPI, Basel, Switzerland. This article is an open access article distributed under the terms and conditions of the Creative Commons Attribution (CC BY) license (https:// creativecommons.org/licenses/by/ $4.0 /)$.

\begin{abstract}
The paper assesses the current state and development trends of the social service system The authors presented the current scheme of the system of social services in Russia and determined that it includes the budgetary, non-profit and commercial sectors. In particular, it is shown that the dominant sector providing social services is the public sector. However, despite the dominant role of the public sector in the provision of social services, in recent years there has been a tendency towards an increasing role of the sector of non-profit (non-budget) and commercial organizations, which have different principles of pricing for social services. For a more complete description and development trends of the social services system in the Russian Federation, the authors determined the most important indicators characterizing the functioning of the social service system and the provision of social services to the population. For a quantitative assessment, a regression model of the dependence of these indicators was created. Analysis of the data in the table shows that, on average, over the past 3 years, the number of recipients of social services in the stationary form of social services has de-creased by $2 \%$ per year, while in the form of social services at home it has grown by $0.25 \%$ per year. The authors determined, that in the future, the demand for inpatient social services will be within the range of recent years, which should not increase the load on the system.
\end{abstract}

Keywords: social service; monitoring; capacity financing; performance regulation; cost differentiation

\section{Introduction}

Social services are one of the most important element of the social and economic system of every country. According to the Federal Law "On the Basics of Social Services for Citizens in the Russian Federation", social services are actions to provide a client with a social service that is provided for and/or does not contradict the current legislation. Social services include social support, provision of social welfare, socio-medical, psychological and pedagogical, social and legal services and material assistance by social services, including social adaptation, rehabilitation of citizens who find themselves in a difficult life situation.

In the recent years there are a lot of research works, dedicated to the problems of the social services and the regional inequality (Williamson 1965), inter-regional inequality (Gluschenko 2017; Glushchenko 2015; Malkina 2015a, 2015b) and public sector institutions (Biryukov et al. 2017), features of social policy in Russia (Tavokin 2020), but there are no significant research works on the characteristics and current trends of the social service system in the Russian Federation, so we decided to focus on this aspect.

In the following article we analyze the current state, the development and the changes in the system of the social services and the legislative base, which exists in Russia at the moment. 
From 12 January 2015, the Federal Law “On the Basics of Social Services for Citizens in the Russian Federation" came into force, according to which social services for citizens are understood as activities to provide citizens with social services.

The federal law also established the principles of social services for citizens, incl. Article 4 of the said law provides that social services are carried out on the following principles: (1) equal, free access of citizens to social services, regardless of their gender, race, age, nationality, language, origin, place of residence, attitude to religion, beliefs and affiliation with public associations; (2) targeting the provision of social services; (3) the proximity of providers of social services to the place of residence of recipients of social services, the sufficiency of the number of providers of social services to meet the needs of citizens in social services, the sufficiency of financial, material, technical, human and information resources from providers of social services; (4) preserving the stay of a citizen in a familiar favorable environment; (5) voluntariness; (6) confidentiality.

The social service system in Russia includes the budgetary, non-profit and commercial sectors.

We determined that the system of social services includes budgetary sector and nonprofit non-budgetary sector. The elements of these sectors are the following:

\subsection{Budgetary Sector}

(1) Authorized federal executive body

(2) Organization of social services under the jurisdiction of the federal executive body

(3) Authorized body of a constituent entity of the Russian Federation

(4) Organization of social services of a constituent entity of the Russian Federation

(5) Authorized organizations

\subsection{Non-Profit Non-Budgetary Sector}

(1) Non-governmental non-profit social service organizations, including socially oriented non-profit organizations providing social services

(2) Non-governmental commercial social service organizations

(3) Individual entrepreneurs providing social services

\subsection{The Social Service System Includes}

(1) the federal executive body responsible for the development and implementation of state policy and legal regulation in the field of social services (authorized federal executive body);

(2) the government body of the constituent entity of the Russian Federation, authorized to exercise the powers provided for by FZ-442 in the field of social services on the territory of the constituent entity of the Russian Federation (authorized body of the constituent entity of the Russian Federation), including the recognition of citizens in need of social services, drawing up an individual program for the provision of social services;

(3) social service organizations under the jurisdiction of federal executive bodies;

(4) social service organizations under the jurisdiction of the constituent entity of the Russian Federation (social service organizations of the constituent entity of the Russian Federation);

(5) non-governmental (commercial and non-commercial) social service organizations, including socially oriented non-commercial organizations that provide social services;

(6) individual entrepreneurs providing social services;

(7) organizations that are under the jurisdiction of the authorized body of the constituent entity of the Russian Federation and which, in accordance with this Federal Law, are empowered to recognize citizens in need of social services and draw up an individual program in the territories of one or several municipalities (authorized organizations). 


\section{Data and Method}

On the basis of statistical data analysis of the Rosstat open-source data and on the basis of the content analysis on the laws, we highlight the main characteristics of the system of the social services in Russia and the main trends. Several forms of social services for citizens are being implemented in the Russian Federation, incl. social services are provided to their recipients in the form of social services at home, or in a semi-stationary form, or in a stationary form. Stationary form means providing social services in the social institution. Semi-stationary form means providing social services partly at the social institution, partly at home. The dominant sector providing social services is the public sector. This can be seen from Figure 1.

This is especially important to take into account when analyzing financial and economic relations within the sphere of social services, since it is the patterns of organizing the activities of the budgetary sector that determine the specific features of the development of this system.

In addition, trends in the structure of social service organizations by sector should be considered. This can be seen at the Figure 2.

The number of organizations belonging to the non-profit, non-budgetary and commercial sector, providing social services in the form of stationary social services, increased 3.6 times over 2 years, and in the form of social services at home-almost 2.1 times. At the same time, for example, the share of stationary organizations belonging to the non-profit non-budgetary and commercial sector increased from $3.1 \%$ to $8.7 \%$.

Thus, despite the dominant role of the public sector in the provision of social services, in recent years there has been a tendency towards an increasing role of the sector of non-profit (non-budget) and commercial organizations, which have different principles of pricing for social services.

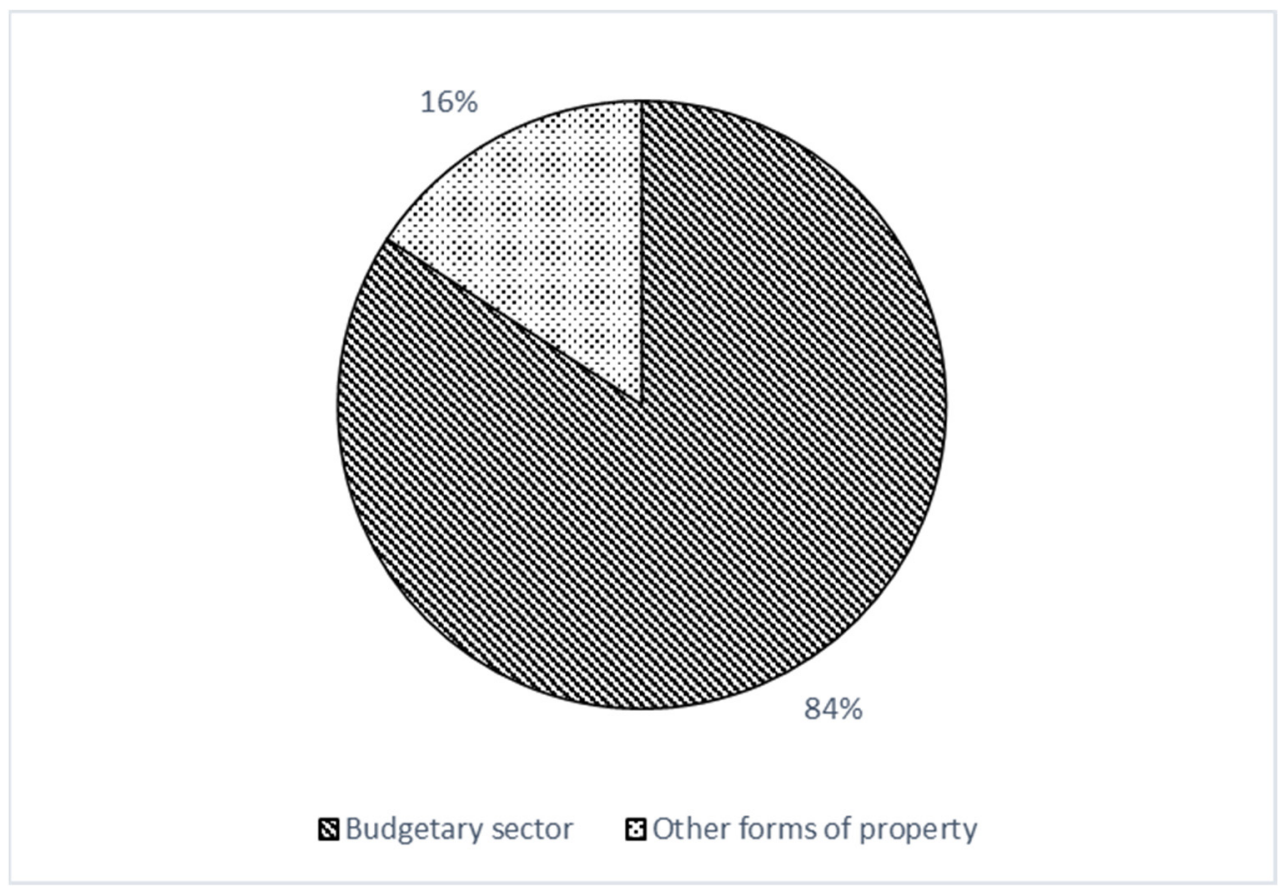

(a) All organizations, forms, \%

Figure 1. Cont. 


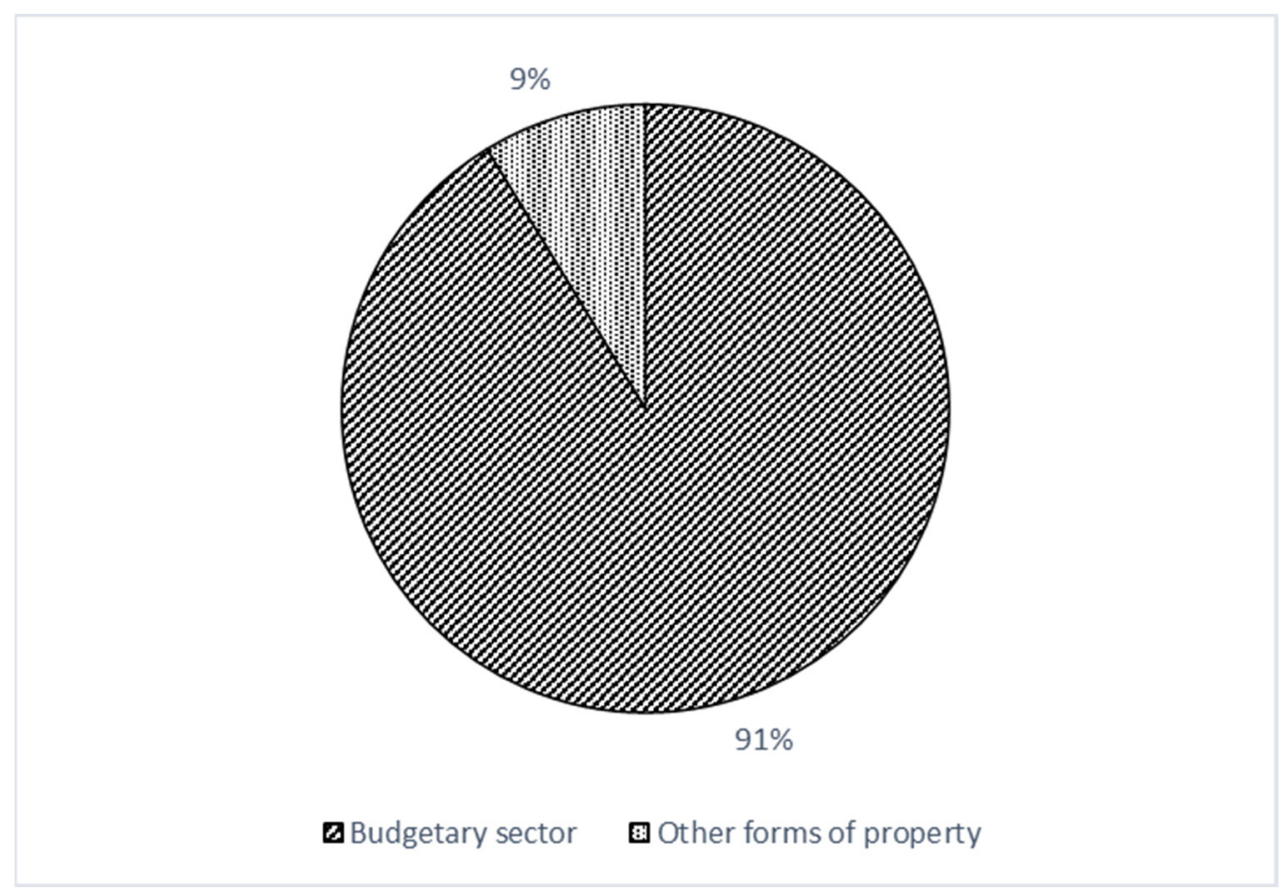

(b) Stationary organizations of social services, forms, \%

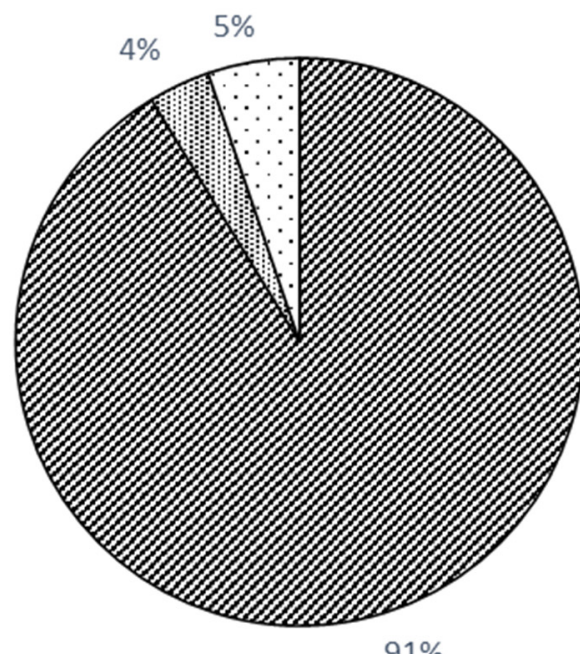

Budget sector $\quad$ B Non-commercial sector $\quad$ Commercial sector

(c) Stationary organizations of social services, by sectors

Figure 1. Cont. 


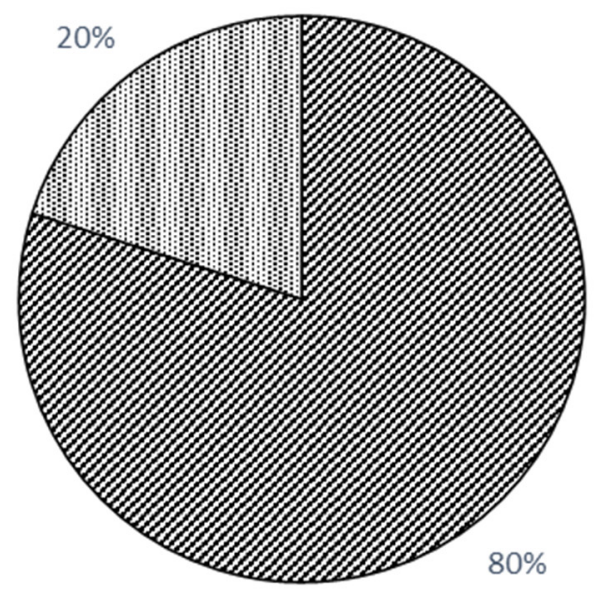

Budgetary sector $\mathbf{0}$ Other forms of property

(d) Semi-stationary organizations of social services, forms, \%

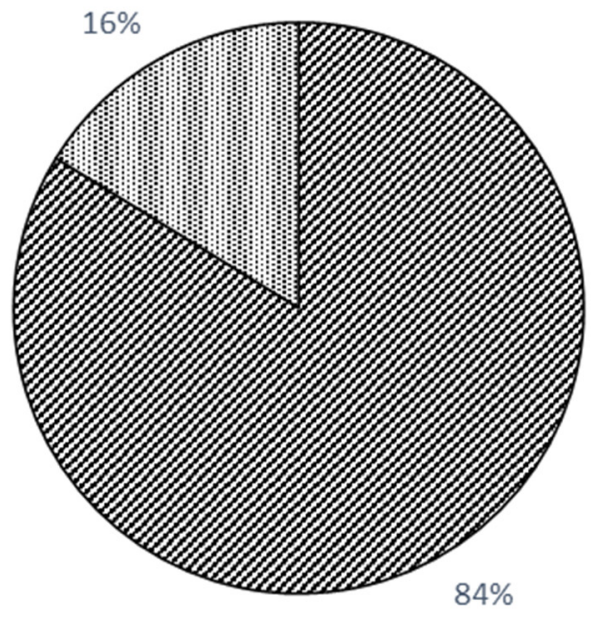

Budgetary sector 国Other forms of property

(e) Organizations, providing social services to their recipients at home, forms, $\%$

Figure 1. Structure of the organizations of the social services. Source: calculations of the authors based on Rosstat official statistics.

For a more complete description and development trends of the social services system in the Russian Federation, it is advisable to consider the characteristics of the functioning of the social service system and the provision of social services to the population. On average, over the past three years, the number of recipients of social services in the stationary form of social services has decreased by $2 \%$ per year, while in the form of social services at home it has grown by $0.25 \%$ per year.

The average capacity of inpatient social service organizations, after a decrease of $8 \%$ in 2017 , subsequently increased by an average of $2 \%$ per year, and the average capacity of semi-stationary social service organizations and organizations providing social services at home grew by an average of $3 \%$ and $2 \%$, respectively. 


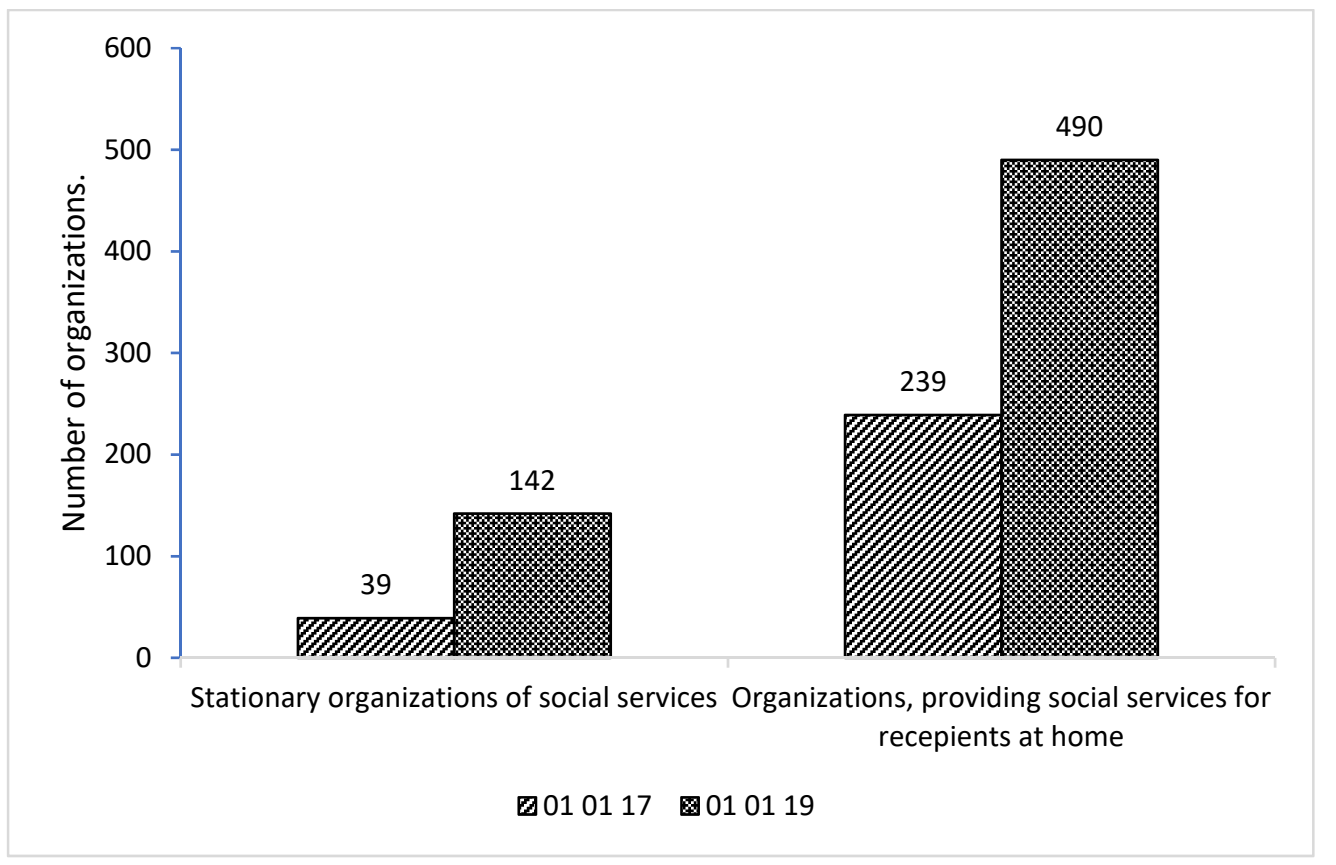

Figure 2. Dynamics of the number of the organizations of the social services in 2017-2019. Source: calculations of the authors based on Rosstat official statistics.

The number of employees of social service organizations, excluding organizations providing social services at home, grew by an average of $4 \%$ in organizations of inpatient social services and $3 \%$ in organizations providing social services in a semi-stationary form. The number of workers in social service organizations providing social services at home declined by an average of $5 \%$ per year. This trend takes place even though the average salary of social workers grew by an average of $17 \%$ annually.

The workload on the staff of social service organizations providing services in the form of social services at home decreased by an average of $2 \%$ per year, while the workload on the main category of personnel of these organizations grew at an average annual rate of $13.5 \%$.

The above indicators largely characterize the quantitative trends in the development of the system of social services for the population, while the most indicative are the qualitative changes. Selected qualitative indicators and trends in the development of the social service system in the Russian Federation are presented in the Table 1.

Analysis of the data in the table shows that, on average, over the past three years, the number of recipients of social services in the stationary form of social services has decreased by $2 \%$ per year, while in the form of social services at home it has grown by $0.25 \%$ per year.

The average capacity of inpatient social service organizations, after being reduced by $8 \%$ in 2017 , subsequently increased by an average of $2 \%$ per year, while the average capacity of semi-stationary social service organizations and organizations providing social services at home grew by an average of $3 \%$ and $2 \%$, respectively.

The number of employees of social service organizations, excluding organizations providing social services at home, grew by an average of $4 \%$ in organizations of inpatient social services and $3 \%$ in organizations providing social services in a semi-stationary form. The number of workers in social service organizations providing social services at home declined by an average of $5 \%$ per year. This trend takes place even though the average salary of social workers grew by an average of $17 \%$ annually. 
Table 1. Dynamics of the number and structure of social service organizations in 2016-2019.

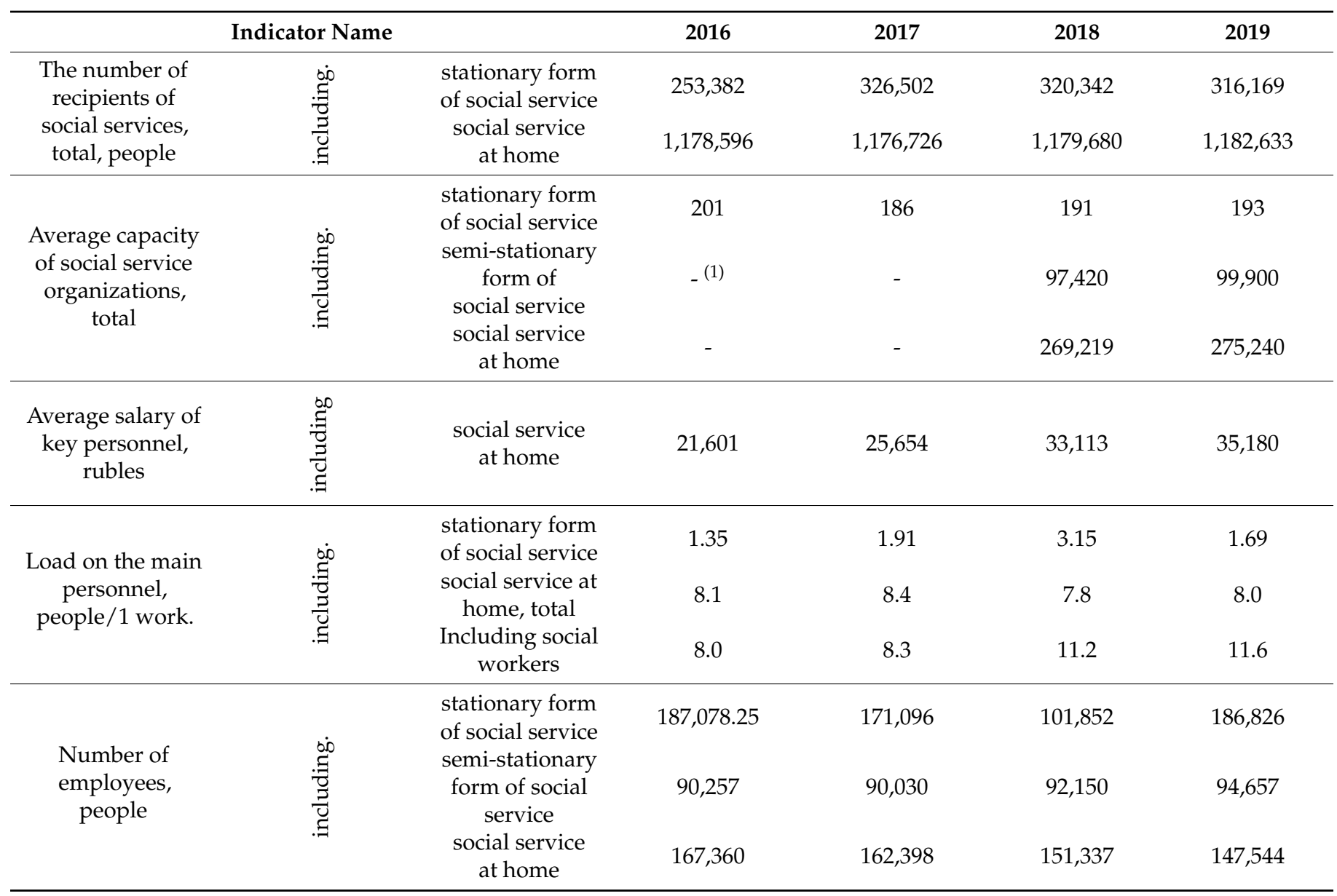

Source: Rosstat. ${ }^{(1)}$ —no data available.

The burden on the staff of social service organizations providing services in the form of social services at home decreased by an average of $2 \%$ per year, while the burden on the main category of personnel of these organizations grew at an average annual rate of $13.5 \%$.

The above indicators largely characterize the quantitative trends in the development of the system of social services for the population, while the most indicative are the qualitative changes. Selected qualitative indicators and trends in the development of the social service system in the Russian Federation are presented in the Table 2.

The most important indicators for judging the state and prospects of development of social services in the medium and long term are the number of social beds per 10,000 people aged 60 years and older and disabled people, and the number of social workers per 10,000 people aged 60 years and older and disabled.

In Table 2 the authors applied the formula $S_{U}=\frac{N_{S}}{N_{S}+N_{P}}$, where $N_{S}$-number of citizens receiving social services; $N_{P}$-the number of citizens on the waiting list for social services (Shorokhova 2015) and (Bashkatov 2002).

As can be seen from the Table 2, if the number of social beds per 10,000 population aged 60 and older and disabled people is growing, which reflects an objective pattern associated with an increase in the proportion of the population over working age, then the number of social workers per 10,000 population aged 60 years and older and disabled people is decreasing, which in the long term will require either significant expenses for attracting social workers to the system of social services, or a significant increase in their labor productivity. 
Table 2. Dynamics of the qualitative changes in the system of social services for the population in the Russian Federation in 2016-2019.

\begin{tabular}{|c|c|c|c|c|c|}
\hline \multicolumn{2}{|l|}{ Indicator Name } & \multirow{2}{*}{$\begin{array}{l}2016 \\
85.0\end{array}$} & \multirow{2}{*}{\begin{tabular}{|c|}
2017 \\
107.1
\end{tabular}} & \multirow{2}{*}{$\begin{array}{c}2018 \\
102.6\end{array}$} & \multirow{2}{*}{$\begin{array}{l}2019 \\
98.8\end{array}$} \\
\hline $\begin{array}{l}\text { Coverage of social services for elderly and } \\
\text { disabled citizens, per } 10,000 \text { population }\end{array}$ & $\begin{array}{l}\text { stationary form of } \\
\text { social service }\end{array}$ & & & & \\
\hline aged 60 and over and disabled, number & social services at home & 395.6 & 386.1 & 377.8 & 369.5 \\
\hline \multicolumn{2}{|c|}{ Satisfaction of the demand for social services, $\%^{1}$} & 96.5 & 97.3 & 97.2 & 97.2 \\
\hline \multicolumn{2}{|c|}{$\begin{array}{l}\text { The number of social beds per 10,000 population aged } 60 \text { and over } \\
\text { and people with disabilities, number }\end{array}$} & 86 & 95 & 92 & 89 \\
\hline \multicolumn{2}{|c|}{$\begin{array}{l}\text { The number of social workers per 10,000 population aged } 60 \text { and } \\
\text { over and disabled, number }\end{array}$} & 56 & 53 & 48 & 46 \\
\hline \multicolumn{2}{|c|}{$\begin{array}{l}\text { The ratio of the wages of a social worker and the subsistence } \\
\text { minimum of the able-bodied population, times }\end{array}$} & 2.20 & 2.54 & 3.22 & 3.23 \\
\hline
\end{tabular}

Source: Rosstat.

It should be especially noted that the growth rate of wages of social workers during the period under review outstripped the growth rate of the average load. However, the standard of living of this category of workers in the social service system during the period under review did not practically change (the growth rate of the ratio of the average wage of a social worker to the subsistence minimum of the working population was $13.7 \%$, and the average annual growth rate of the workload was 13.5\%). Apparently, it is this tendency, together with the nature of labor in this profession, that can be considered a factor in reducing the supply of their labor.

One of the most important characteristics of the system of social services for the population is its ability to meet the needs of citizens in social services in the future.

The share of citizens over working age who receive social services in the form of social services at home exceeds $73 \%$, and in the stationary form of social services, more than $46 \%$ (Figure 3).

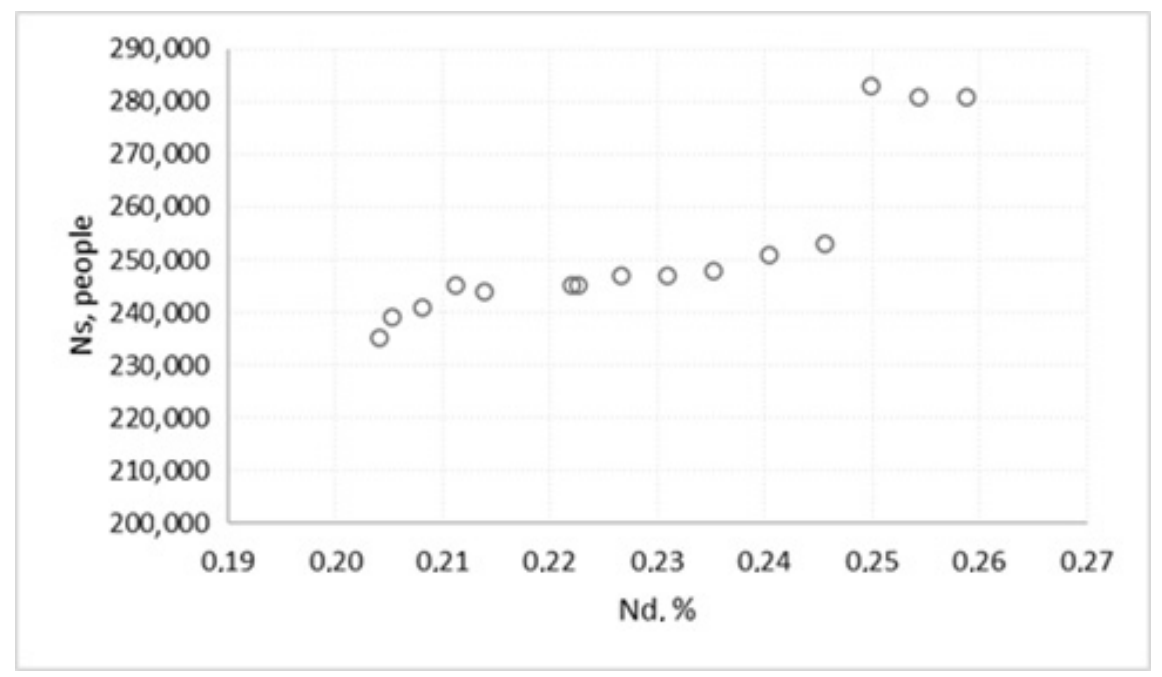

Figure 3. Dependence of the number of recipients of social services on the proportion of the elderly population over working age. Source: calculations of the authors based on Rosstat official statistics.

It can be assumed that the demand for social services is functionally related to the proportion of elderly people. To test this hypothesis, a correlation analysis was carried out, which showed a close relationship between these indicators for home-based services $\left(r_{N_{d}, N_{s}}=0.87\right)$. 
For a quantitative assessment, a regression model of the dependence of the above indicators was built, the assessment results of which have the following form (Figure 4):

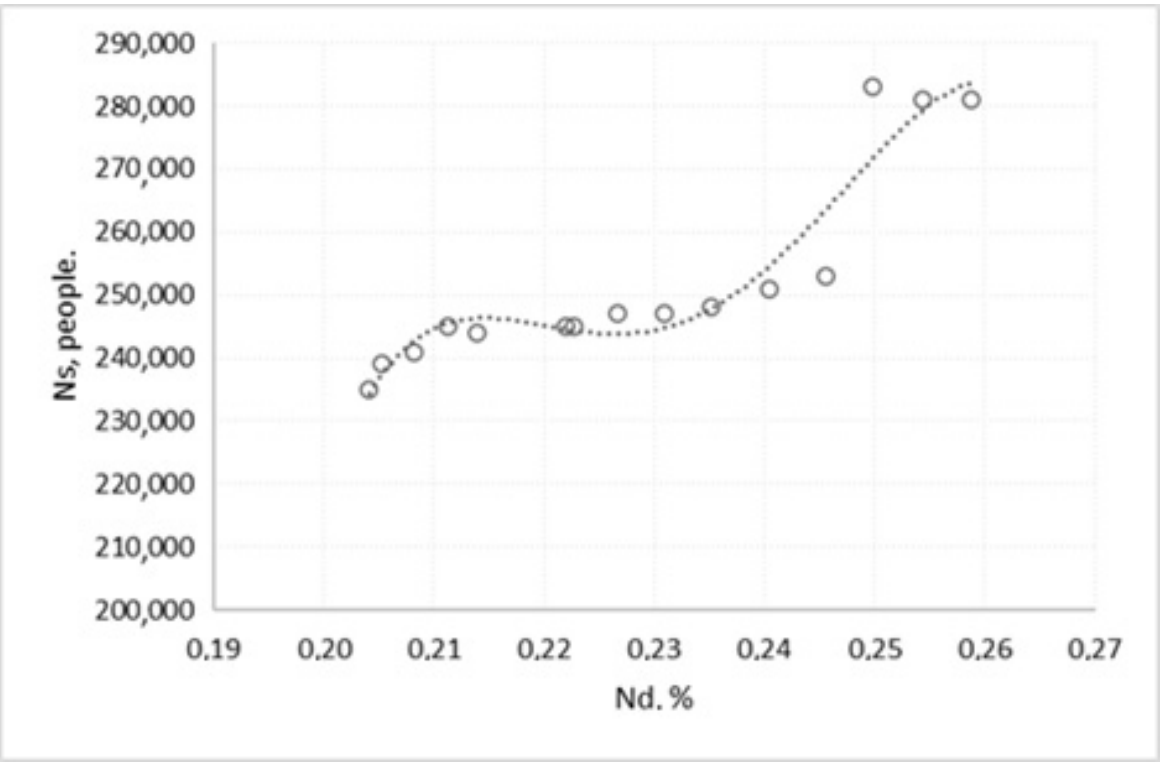

Figure 4. Results of modeling the demand for inpatient social services. Source: calculations of the authors based on Rosstat official statistics.

The coefficient of determination is $R^{2}=0.89$; the regression equation as a whole and the coefficients are statistically significant at the $p<0.05$ level.

Using the data of the demographic forecast, it is possible to estimate the future demand for social services in a stationary form (Figure 5).

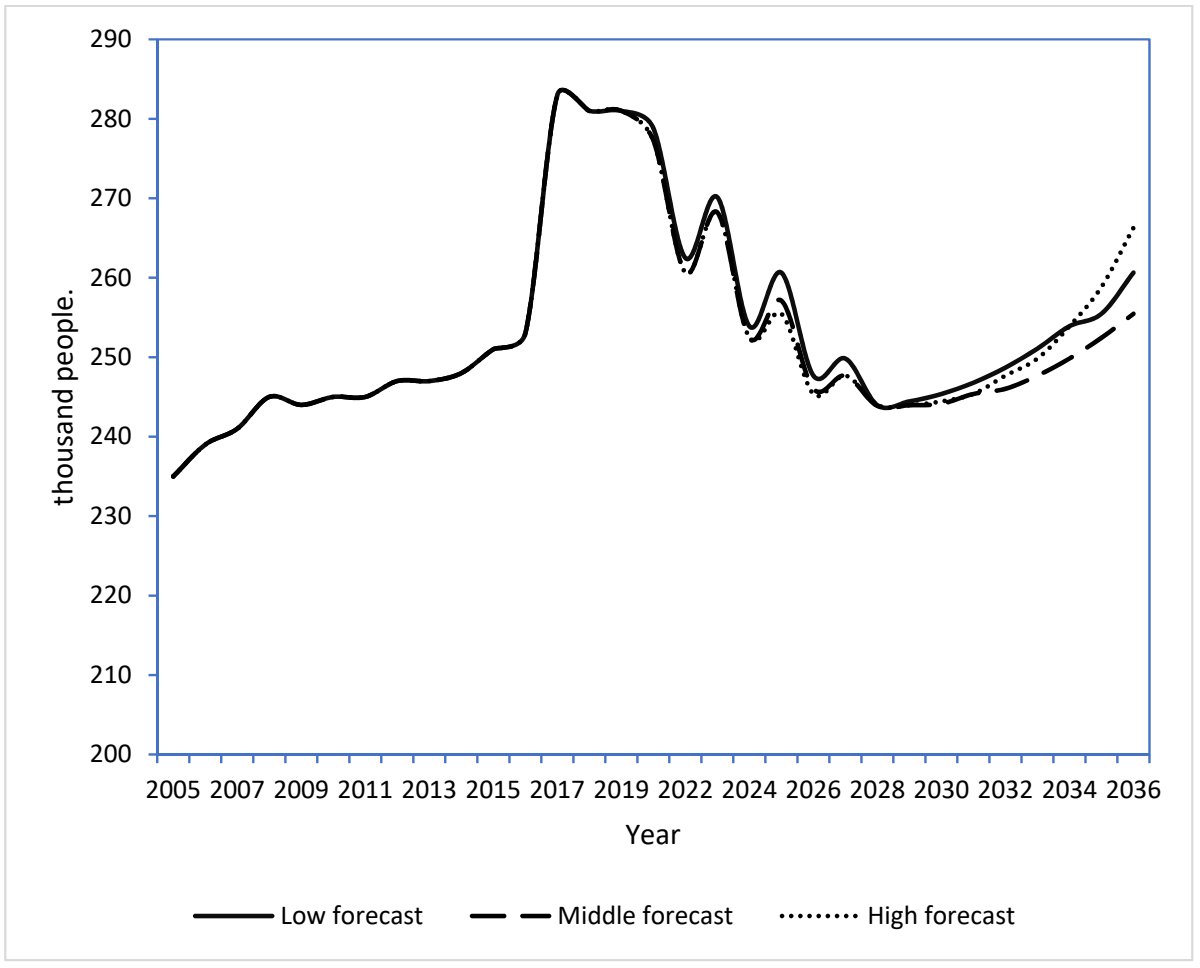

Figure 5. Forecast of demand for inpatient social services (2021-2036). Source: calculations of the authors based on Rosstat official statistics. 
As can be seen from the above graph, in the future, the demand for inpatient social services will be within the range of recent years, which should not increase the load on the system.

\section{Conclusions and Policy Implications}

As a result of interim studies, it was found that the indicators of the functioning of the social service system vary significantly. This creates unequal conditions for the activities of social service organizations and violates the guarantees of recipients of social services for affordable social services. The novelty of the study covers the following aspects. The authors developed the scheme of the system of social services in Russia. The authors determined that it includes the budgetary, non-profit and commercial sectors and the dominant sector providing social services is the public sector. Methodological aspects of assessing and analyzing the differentiation of the parameters of the functioning of the social service system have not yet been developed. The authors determined the indicators of the dynamics of the number and structure of social service organizations in 2016-2019 and the dynamics of their qualitative changes. As the result of the study, for a quantitative assessment, a regression model of the dependence of these indicators was created. Analysis of the data in the table shows that, on average, over the past three years, the number of recipients of social services in the stationary form of social services has decreased by $2 \%$ per year, while in the form of social services at home it has grown by $0.25 \%$ per year. The authors determined, that in the future, the demand for inpatient social services will be within the range of recent years, which should not increase the load on the system.

Author Contributions: The authors contributed equally to this paper. Conceptualization, M.V.D., V.M.S. and M.A.S.; Methodology, M.V.D., V.M.S. and M.A.S.; Software, M.V.D., V.M.S. and M.A.S.; Validation, M.V.D., V.M.S. and M.A.S.; Formal analysis, M.V.D., V.M.S. and M.A.S.; Investigation, M.V.D., V.M.S. and M.A.S.; Resources, M.V.D., V.M.S. and M.A.S.; Data curation, M.V.D., V.M.S. and M.A.S.; Writing—original draft preparation, M.V.D., V.M.S. and M.A.S.; Writing—review and editing, M.V.D.; Visualization, M.V.D., V.M.S. and M.A.S.; Supervision, M.V.D.; Project administration, M.V.D., V.M.S. and M.A.S.; Funding acquisition, M.V.D., V.M.S. and M.A.S. All authors have read and agreed to the published version of the manuscript.

Funding: This research received no external funding.

Institutional Review Board Statement: Not applicable.

Informed Consent Statement: Informed consent was obtained from all subjects involved in the study.

Data Availability Statement: The data supporting reported results can be found in Rosstat official publications by the following links to publicly archived datasets analyzed and generated during the study: https:/ / rosstat.gov.ru/folder/10705 (accessed on 17 January 2022).

Conflicts of Interest: The authors declare no conflict of interest.

\section{Notes}

1 The following formula was used: $S_{U}=\frac{N_{s}}{N_{s}+N_{P}}$, where $N_{S}$-number of citizens receiving social services; $N_{P}$-the number of citizens on the waiting list for social services.

\section{References}

Bashkatov, B. I., ed. 2002. Socio-Economic Statistics: Textbook for University Students Studying in the Specialty 061700 "Statistics" and Other Econom. Specialties. Moscow: UNITI, p. 71.

Biryukov, A., D. A. Dombrovsky, and E. E. Komarovskaya. 2017. Reform of Public Sector Institutions: Preliminary Results and New Challenges [Text]. Edited by A. M. Lavrov and O. K. Yastrebova. Moscow: National Research University Higher School of Economics, Faculty of Social Sciences, Department of State and Municipal Administration.

Gluschenko, K. P. 2017. 'Williamson's Fallacy' in Estimation of Inter-Regional Inequality. Estimation of Inter-Regional Inequality (20 November 2015). MPRA Paper. pp. 1-39. Available online: https://www.researchgate.net/publication/317237016_ $\backslash \mathrm{T} 1 \backslash$ textquoterightWilliamson $\backslash \mathrm{T} 1 \backslash$ textquoterights_Fallacy $\backslash \mathrm{T} 1 \backslash$ textquoteright_in_Estimation_of_Inter-Regional_Inequality (accessed on 17 January 2022).

Glushchenko, K. P. 2015. On the assessment of interregional inequality. Spatial Economics 4: 39-58. 
Malkina, M. Yu. 2015a. Study of the factors of interregional convergence/divergence in real incomes and "social well-being" of Russian regions. Journal of Economic Regulation 6: 111-19. [CrossRef]

Malkina, M. Yu. 2015b. Investigation of factors of interregional convergence/divergence of real incomes and "Social welfare" of the regions of the Russian Federation. Journal of Economic Regulation (Issues of Economic Regulation) 6: 113.

Shorokhova, I. S. 2015. Statistical Methods of Analysis: [Textbook. Manual]. Edited by I. S. Shorokhova, N. V. Kislyak and O. S. Mariev. Urals/Federer: Ministry of Education and Science Ros. Federation. Yekaterinburg: Publishing house in the Urals University, p. 82.

Tavokin, E. P. 2020. Features of social policy in modern Russia. Sociology International Journal 4: 183-87. [CrossRef]

Williamson, Jeffrey G. 1965. Regional inequality and the process of national development: A description of patterns. Economic Development and Cultural Change 13: 1-84. [CrossRef] 